\title{
Numerical analysis of the efficiency and energy production of the building integrated photovoltaics for various configurations
}

\author{
Sebastian Valeriu Hudișteanu ${ }^{1, *}$ and Cătalin George Popovici ${ }^{1}$ \\ 1"Gheorghe Asachi" Technical University of Iaşi, Faculty of Civil Engineering and Building Services, Romania
}

\begin{abstract}
The paper presents the analysis of the building integrated photovoltaic panels (BIPV) realized for the same photovoltaic system, placed in different locations, for the continental climate of Romania. For all studied cases, the photovoltaic (PV) system is examined in various vertical configurations, considering the integration into buildings placed in urban agglomerations, characterized by small horizontal surfaces, but generous facades. For the analyzed situations it is assumed that the PV panels are fixed in vertical position. Therefore, one of the possibilities of raising their efficiency consists in controlling the operating temperature of the photovoltaic cells. The operating parameters of the photovoltaic panels are studied in case of integration at $10 \mathrm{~m}$ height above the ground and the results are reported on the unit surface. The model and the functioning parameters are processed using TRNSYS software. The results are analyzed for average daily, monthly and yearly values. The results reveal some major differences obtained for the same system placed in different locations or orientations. The average efficiencies for maximum production months are lower than annual ones, while the daily values for efficiency are lowest. These values are directly dependent on the intensity of solar radiation and are negatively influenced by the operating temperature of the photovoltaic panel.
\end{abstract}

\section{Introduction}

The photovoltaic effect is the most wide-spread solution for converting solar energy into electricity. The effect is achieved by using different types of photovoltaic (PV) cells [1]. The first reports over the photovoltaic conversion were made by Adams and Day, 1876 [2], while the modern PV cells were discovered by Chapin and Fuller, who reported an initial $4.5 \%$ efficiency of the silicon PV cells [1].

Modern photovoltaic cells are made of different semiconductors, such as silicon, germanium, gallium and others [3]. A remarkable aspect is that almost $90 \%$ of PV cells are made of Si [4], a wide-spread material, which thanks to technological advancement became affordable to vast majority of population $[6,7]$. On the other hand, taking into account the raising price of fossil fuels corroborated with low reserves [5], the PV systems are recommended to be implemented at the current moment and in near future. The price of PV cells in $\$ / \mathrm{Wp}$ is following the Swanson law [8], which states that the price of PV panels is decreasing by $20 \%$ for each doubling of worldwide installed power [9].

One of the most important characteristics of a PV panel consists in its conversion efficiency. It actually expresses the quantity of electric power obtained from solar radiation in certain conditions. The most efficient silicon solar cells are the mono-crystalline ones, with typical maximum values of the efficiency in Standard Test Conditions (STC) between 14\% ...17\% [10].

\footnotetext{
* Corresponding author: sebastian.hudisteanu@tuiasi.ro
}

One of the most harmful effect over the functioning of photovoltaic cells is represented by the inversely proportional dependency of the efficiency $(\eta)$ and open circuit voltage $\left(V_{o c}\right)$ with the operating temperature $\left(T_{c e l l}\right)$. This is a consequence of low direct conversion of solar radiation into electricity which leads to an approximate $80 \%$ conversion into heat $[11,12]$. There are many studies in literature referring to this dependence [13], most of them considering a linear variation of open circuit voltage $\left(V_{o c}\right)$ and maximum power $\left(P_{m p}\right)$ with cell's temperature. The decrease of efficiency is approximately $0.3 \ldots 0.5 \%$ for each degree over $25^{\circ} \mathrm{C}[14,15]$.

For the situations when it is assumed that the PV panels are in a fixed position, in particular case of placing them integrated into buildings, on facades or roofs, one of the possibilities of raising their efficiency is by controlling the operating temperature of the cells.

There is an important number of studies in literature regarding the methods of reduction the operating temperature of PV panels and correlations between efficiency and operating temperature of PV cells [16]. Some of the solutions to improve the temperature of photovoltaic panels by using the air and passive cooling are presented in important works $[17,18,19,20]$.

The Building Integrated Photovoltaics (BIPV) represents a possible solution of using PV panels near the consumption area $[21,22]$. This technology consists in integration of PV panels into the façades of the building creating an active wall or active façade [23, 24]. Thus, the PV panels are replacing zones of the exterior or interior glazing, creating cold or hot facades. 
Considering the integration of PV panels into buildings placed in urban agglomerations, characterized by small horizontal surfaces, but generous facades, the BIPV technique may be a viable solution for using the available surface of the building's façades [25-28].

The literature presents a series of works focused on the numerical analysis of PV systems placed on the roof of buildings [29-33] or regarding BIPV/T systems [35] and in generally, all cooling solutions come with the recommendation that the gain of thermal energy to be used for other applications. In this way, the payback period can be considerably reduced comparing to the stand-alone PV system.

\section{Problem description}

The main objective of this paper is to determine through numerical simulation the efficiency of PV panels in different locations of a temperate climate territory. Therefore, a PV panel with $1 \mathrm{~m}^{2}$ surface is considered, integrated into the façade of a building for variable locations and orientations. The reference PV panel is composed of 36 photovoltaic cells connected in series. The purpose of the analysis consists in determining the most advantageous situation of integration, regarding the maximum energy production, for different geographical situations. The annual, monthly and daily analysis was achieved by using the TRNSYS software.

The analysis includes four of the most important urban areas located in Romania. These cities, characterized by slightly different climatic conditions, have the following geographical coordinates:

- Bucharest $\left(44^{\circ} 26^{\prime} 10.1^{\prime \prime} \mathrm{N}, 26^{\circ} 06^{\prime} 03.4^{\prime \prime} \mathrm{E}\right)$

- Iasi $\left(47^{\circ} 09^{\prime} 06.9^{\prime \prime} \mathrm{N}, 27^{\circ} 35^{\prime} 13.1^{\prime \prime} \mathrm{E}\right)$

- Timisoara $\left(45^{\circ} 45^{\prime} 23.9^{\prime \prime} \mathrm{N}, 21^{\circ} 13^{\prime} 43.2^{\prime \prime} \mathrm{E}\right)$

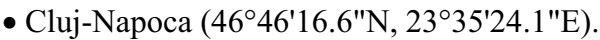

The analysis is focused on the PV panel's energy production and does not concern the entire PV system efficiency.

\section{Numerical simulation}

In Fig. 1 is presented the block diagram used in TRNSYS software. The weather conditions ( $G$ - solar radiation and $T_{\text {ext }}$ - external temperature) used in simulations are based on Typical Meteorological Year (TMY - Type 109) [36]. The components regarding weather conditions are variable during the yearly, monthly and daily cycle.

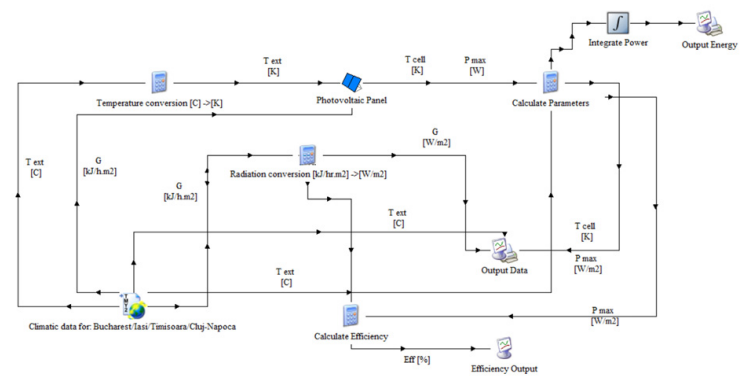

Fig. 1. The block diagram used for numerical analysis
The recommended unit for the PV panel modelling is Type 94. This block is used in simulations, being appropriate for both monocrystalline or polycrystalline silicon PV modules. The four parameters model [30] used for a more realistic PV panel functioning and evaluation is described by the following equations which are taking into account both series $\left(R_{s}\right)$ and shunt $\left(R_{s h}\right)$ resistances $[34,35]$. The current, $I$, generated by $\mathrm{PV}$ cell is determined using Eq. 1:

$$
I=I_{p h}-I_{D}\left(\exp \frac{q\left(V+R_{S} I\right)}{n K T_{\text {cell }}}-1\right)-\frac{\left(V+R_{S} I\right)}{R_{s h}}
$$

The open circuit voltage $\left(V_{o c}\right)$ of the cell is calculated using Eq. 2:

$$
V_{o c}=\frac{n K T_{c e l l}}{q} \ln \left(\frac{I_{p h}}{I_{D}}+1\right)
$$

Tab. 1 presents the dimensions and parameters of the photovoltaic panel studied in this paper [36].

\begin{tabular}{|c|c|c|}
\hline Parameters & Input Data & Output Data \\
\hline$S=1 \mathrm{~m}^{2}$ & \multirow{9}{*}{$\begin{array}{l}\text { - orientation of PV } \\
\text { panel: - south, south- } \\
\text { east, south-west; } \\
\text { - position of PV panel: } \\
\text { vertical; } \\
\text { - climatic conditions: } \\
\text { Bucharest, Iasi, } \\
\text { Timisoara and Cluj- } \\
\text { Napoca, according to } \\
\text { TMY; } \\
\text { - analysis interval: } \\
\text { annual, monthly and } \\
\text { daily. }\end{array}$} & \multirow{9}{*}{$\begin{array}{l}\text { - PV panel } \\
\text { efficiency; } \\
\text { - maximum power, } \\
\text { current and } \\
\text { voltage produced; } \\
\text { - operating } \\
\text { temperature of PV } \\
\text { panel; } \\
\text { - energy produced } \\
\text { by PV panel. }\end{array}$} \\
\hline$I_{s c}=6,5 \mathrm{~A}$ & & \\
\hline$V_{o c}=21,6 \mathrm{~V}$ & & \\
\hline$I_{\max }=5,9 \mathrm{~A}$ & & \\
\hline$V_{\max }=17 \mathrm{~V}$ & & \\
\hline$t_{\text {NOCT }}=47^{\circ} \mathrm{C}$ & & \\
\hline$V_{o c}=-0.079$ & & \\
\hline$T_{r e f}=25^{\circ} \mathrm{C}$ & & \\
\hline$G_{r e f}=1000 \mathrm{~W} / \mathrm{m}^{2}$ & & \\
\hline
\end{tabular}

Table 1. Parameters, inputs and outputs of the model.

\section{Results and discussions}

The qualitative and quantitative information about the results of simulations are synthesized both as images, Fig. 2 - Fig. 22, and numerical data, Tab. 2 and Tab. 3. The values referring to solar insolation and operating temperature are registered on the PV panel surface, being presented for Bucharest location only, Fig. 2 - Fig. 7. The yearly and monthly analysis is presented with detailed information for all locations, in Fig. 8 - Fig. 19, while for the daily results, only the Bucharest case is figured Fig. 20 - Fig. 22. The results referring to all cities are centralized in Tab. 2 and Tab. 3.

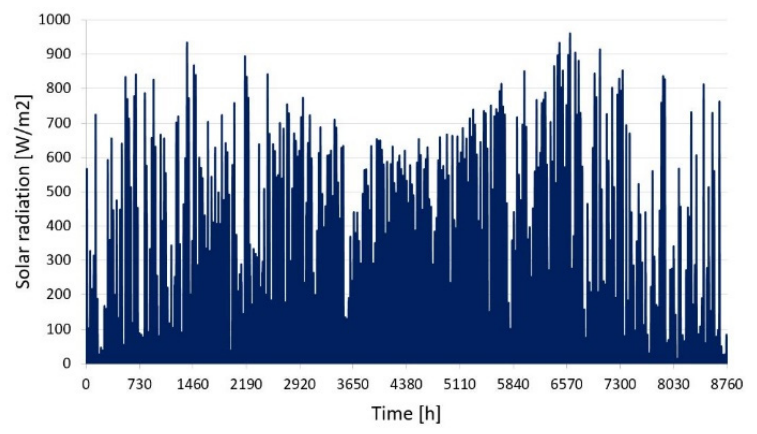

Fig. 2. Bucharest - Yearly variation of solar radiation incident on PV panel - Vertical-South 


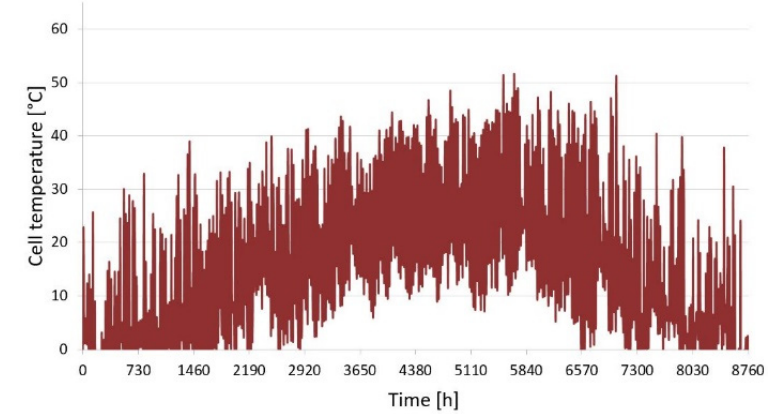

Fig. 3. Bucharest - Yearly variation of operating temperature of PV panel-Vertical-South

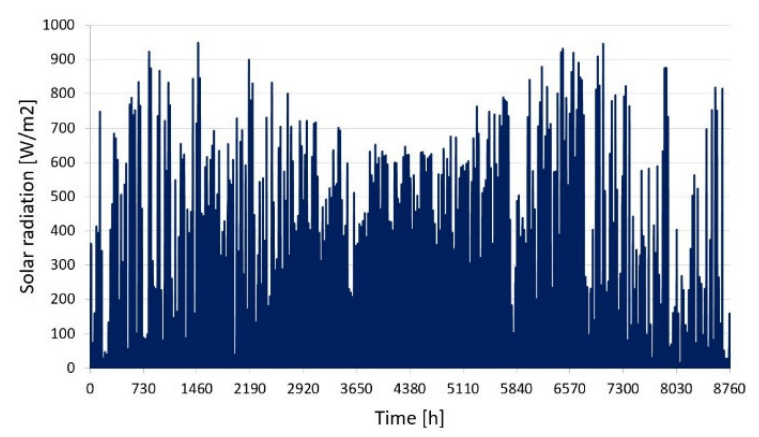

Fig. 4. Bucharest - Yearly variation of solar radiation incident on PV panel - Vertical-South-East

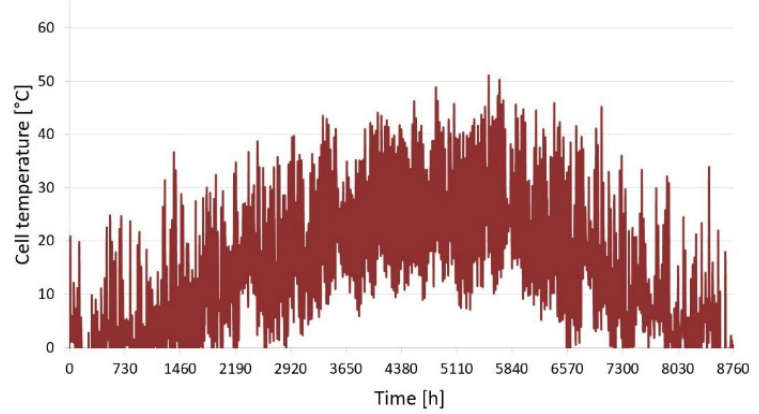

Fig. 5. Bucharest - Yearly variation of operating temperature of PV panel - Vertical-South-East

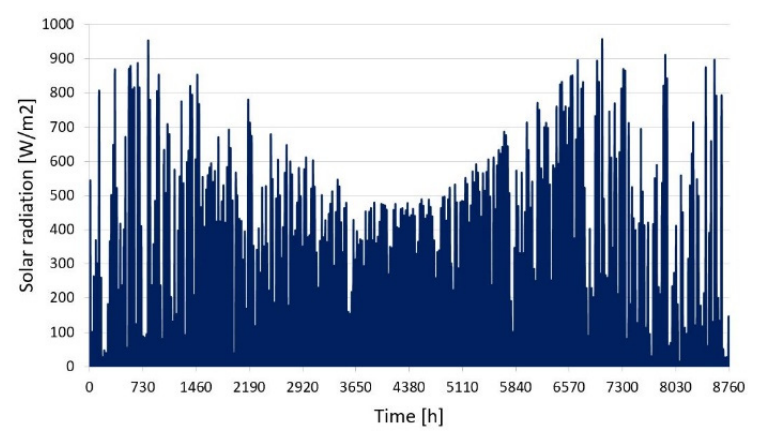

Fig. 6. Bucharest - Yearly variation of solar radiation incident on PV panel - Vertical-South-West

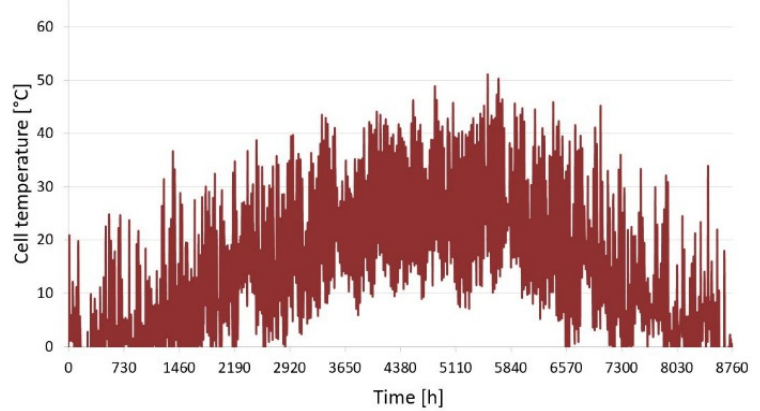

Fig. 7. Bucharest - Yearly variation of operating temperature of PV panel - Vertical-South-West

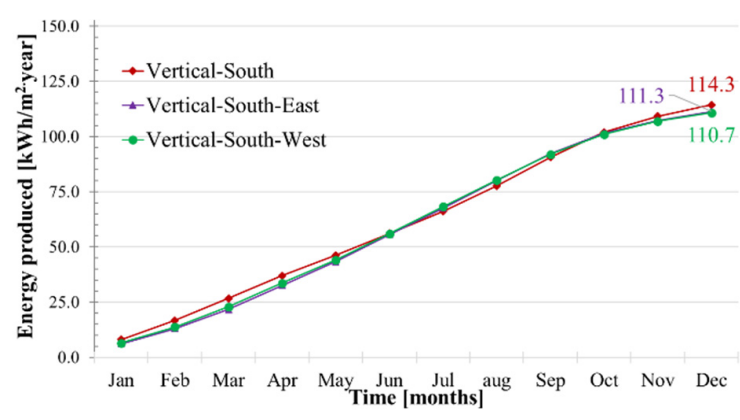

Fig. 8. Bucharest - yearly energy produced $\left[\mathrm{kWh} / \mathrm{m}^{2}\right.$ year $]$

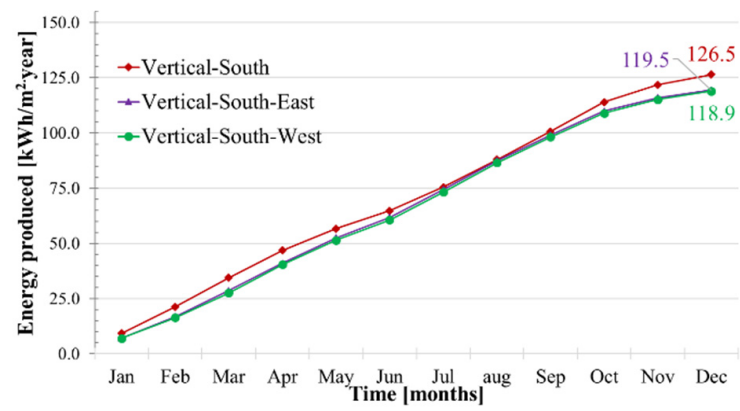

Fig. 9. Cluj-Napoca - yearly energy produced $\left[\mathrm{kWh} / \mathrm{m}^{2}\right.$ year $]$

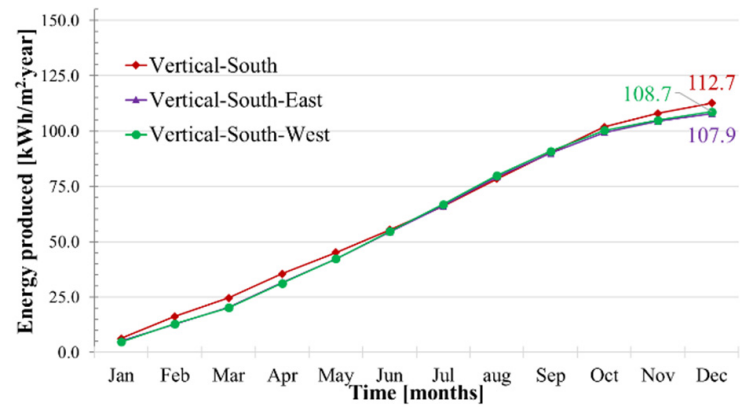

Fig. 10. Iasi - yearly energy produced $\left[\mathrm{kWh} / \mathrm{m}^{2}\right.$ year $]$

For each studied case, the highest values of monthly efficiency are reached for winter, early spring and late autumn months (over 11.50\%). The negative aspect is the inversely dependence between monthly energy produced and corresponding efficiency.

On the other hand, for the three months interval with maximum energy production, the minimum efficiency is registered. The main reason consists in high operating temperatures of PV panel during this period. For vertical analysis, the maximum monthly energy production 
reaches $13.4 \mathrm{kWh} / \mathrm{m}^{2}$ month for vertical-south orientation and between 12.3-13.0 kWh/m $\mathrm{m}^{2}$ month for vertical-southeast and vertical-south-west, while the maximum cell temperatures are often over $50-55^{\circ} \mathrm{C}$. The lower energy production is determined mainly by lower values of solar radiation registered on vertical surfaces or by narrower intervals when the sunlight is incident on PV panel's surface.

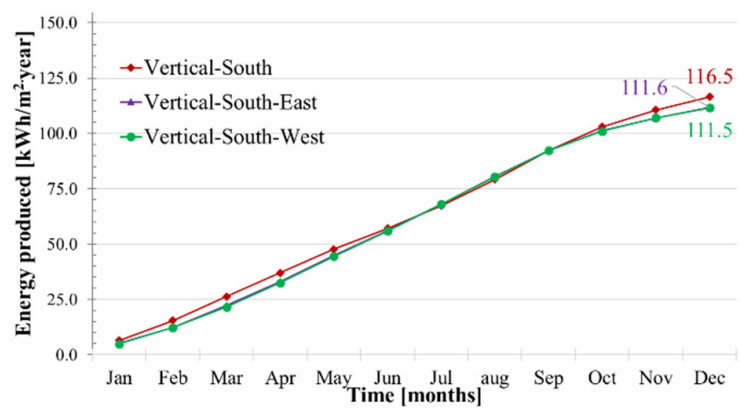

Fig. 11. Timisoara - yearly energy produced $\left[\mathrm{kWh} / \mathrm{m}^{2}\right.$ year $]$

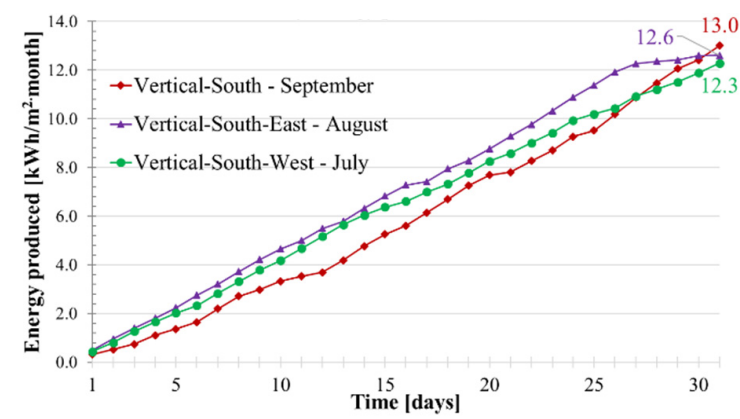

Fig. 12. Bucharest - monthly energy produced $\left[\mathrm{kWh} / \mathrm{m}^{2}\right.$ month $]$

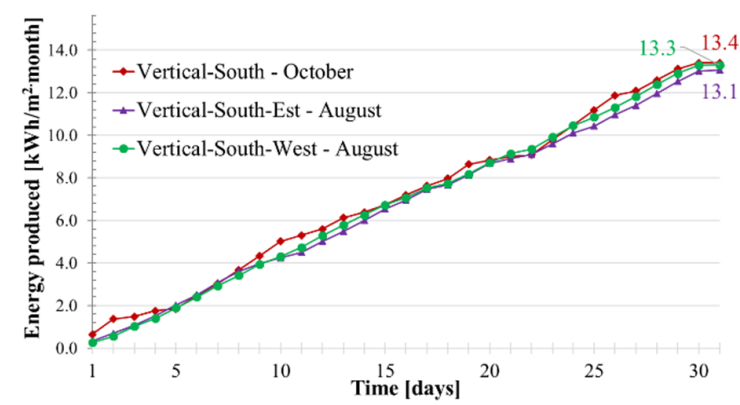

Fig. 13. Cluj-Napoca - monthly energy produced $\left[\mathrm{kWh} / \mathrm{m}^{2}\right.$ month $]$

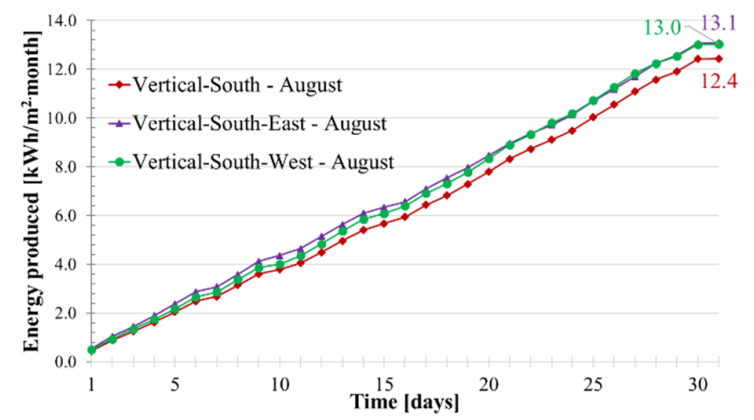

Fig. 14. Iasi - monthly energy produced $\left[\mathrm{kWh} / \mathrm{m}^{2}\right.$ month]

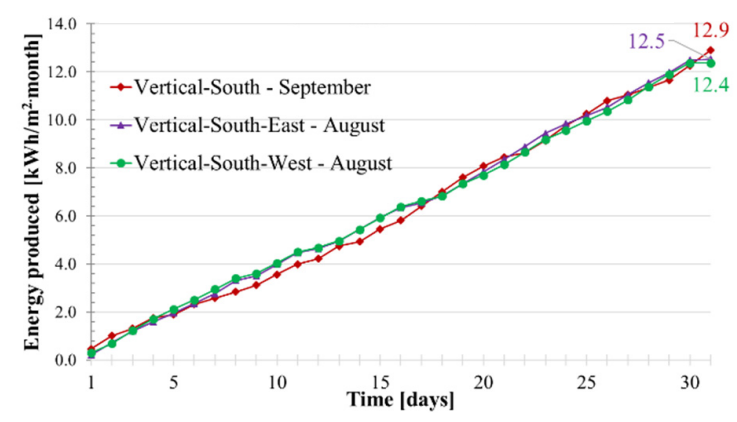

Fig. 15. Timisoara - monthly energy produced $\left[\mathrm{kWh} / \mathrm{m}^{2} \cdot \mathrm{month}\right]$

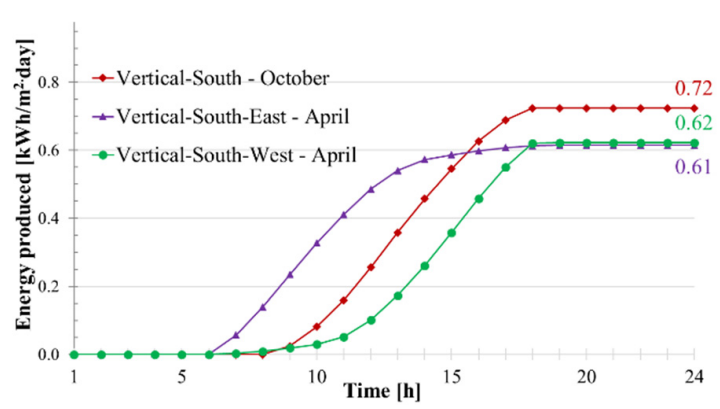

Fig. 16. Bucharest - daily energy produced $\left[\mathrm{kWh} / \mathrm{m}^{2}\right.$ day $]$

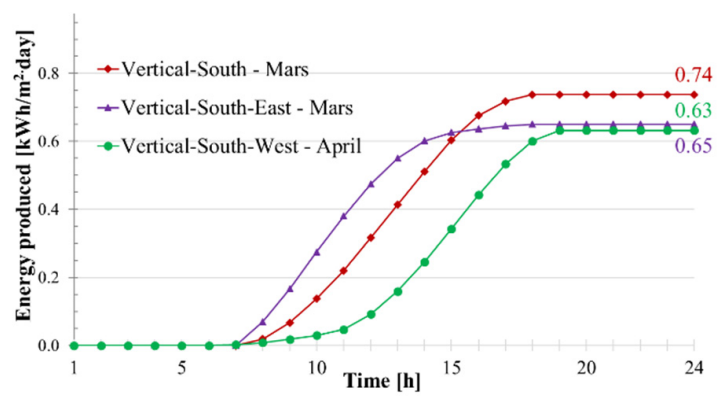

Fig. 17. Cluj-Napoca - daily energy produced $\left[\mathrm{kWh} / \mathrm{m}^{2}\right.$ day]

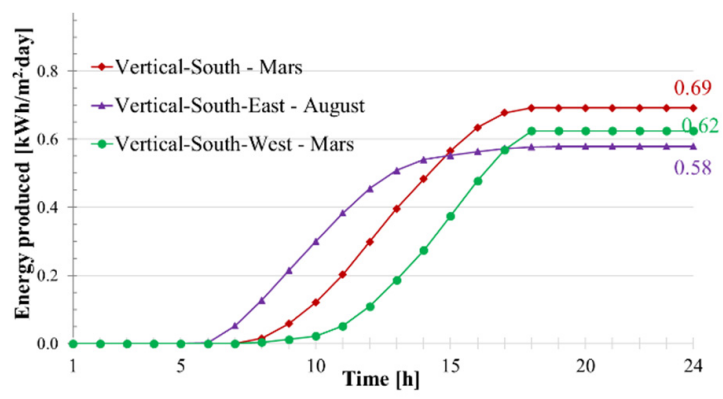

Fig. 18. Iasi - daily energy produced $\left[\mathrm{kWh} / \mathrm{m}^{2}\right.$ day $]$

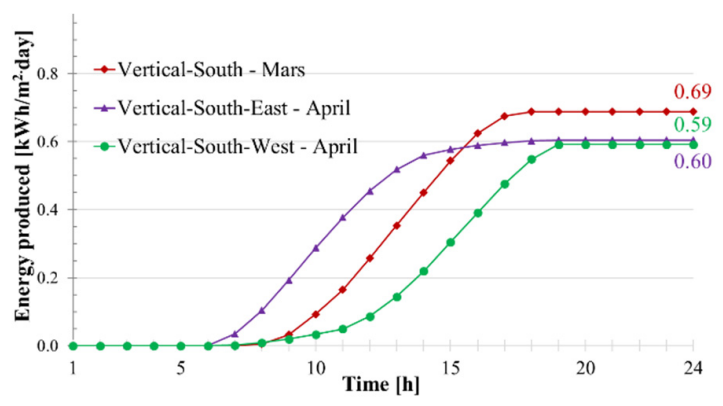

Fig. 19. Timisoara - daily energy produced $\left[\mathrm{kWh} / \mathrm{m}^{2}\right.$ day $]$ 
In terms of efficiency, for vertical integration, the minimum monthly efficiencies are also registered in hot days of summer, even the incident solar radiation is limited under $600-700 \mathrm{~W} / \mathrm{m}^{2}$. Also, when analyzing the studied vertical cases, it can be remarked the uniformity of the energy production during the entire year. Thus, for vertical position the ratio of minimum monthly energy produced to the maximum one is about 0.390 , while compared to the annual average it is 0.533 for verticalsouth, 0.368 and 0.436 for vertical-south-east, 0.318 and 0.422 for vertical-south-west orientation. Therefore, the most uniform distribution of the energy produced over the year is achieved by using a vertical-south positioning for the PV system. This case also assures maximum annual, monthly and daily energy production at efficiencies approximately equal to the other vertical positions studied.

Information regarding the parameters obtained during the maximum day, Fig. 20 - Fig. 22, also revealed that the variation of PV panel's temperature is dependent on solar insolation and external temperature. The maximum power produced is dependent on solar insolation and inversely proportional to the cells operating temperature.

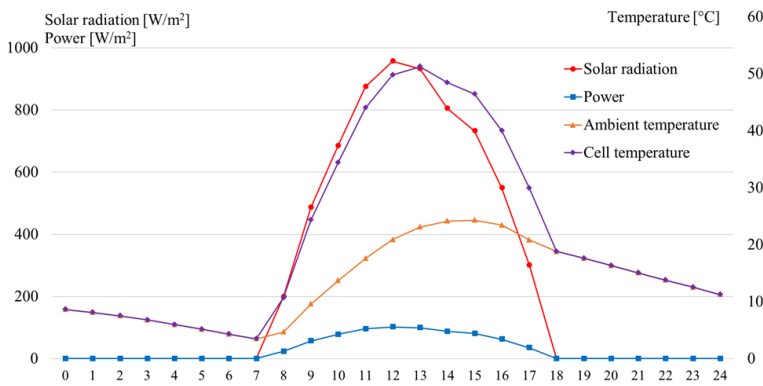

Fig. 20. Bucharest - Parameters for maximum day of production (October) - Vertical South

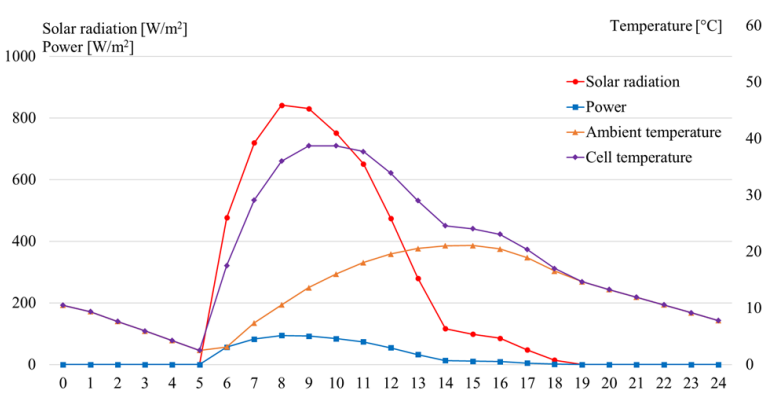

Fig. 21. Bucharest - Parameters for maximum day of production (April) - Vertical South-East

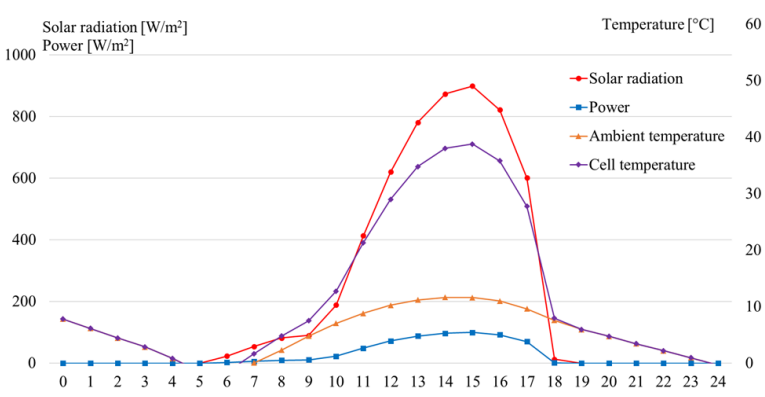

Fig. 22. Bucharest - Parameters for maximum day of production (April) - Vertical South
More accurate quantitative results are shown in the following tables. Tab. 2 presents the yearly amount of energy produced by PV panel. The best configuration is achieved for placing the PV panel in vertical-south position. Taking into account the BIPV analysis, in vertical position south, south-east and south-west orientations, almost a maximum of $126.5 \mathrm{kWh} / \mathrm{m}^{2}$ year are obtained, while the annual efficiency is about $11.61 \%$. The annual production is ranging between 107.9-126.5 $\mathrm{kWh} / \mathrm{m}^{2}$ year. The most advantageous case for vertical position is Cluj-Napoca, for all studied orientations. The lowest annual energy production for all cases resulted to be in Iasi.

Table 2. Results for yearly analysis.

\begin{tabular}{|c|c|c|c|c|c|}
\hline \multicolumn{2}{|c|}{ Position / Location } & B & CJ & IS & TM \\
\hline Vertical- & $E\left[\mathrm{kWh} / \mathrm{m}^{2} \cdot \mathrm{y}\right]$ & 114.29 & 126.49 & 112.68 & 116.52 \\
\cline { 2 - 6 } S & $\eta[\%]$ & 11.60 & 11.61 & 11.63 & 11.58 \\
\hline Vertical- & $E\left[\mathrm{kWh} / \mathrm{m}^{2} \cdot \mathrm{y}\right]$ & 111.29 & 119.46 & 107.9 & 111.64 \\
\cline { 2 - 6 } SE & $\eta[\%]$ & 11.62 & 11.64 & 11.66 & 11.61 \\
\hline Vertical- & $E\left[\mathrm{kWh} / \mathrm{m}^{2} \cdot \mathrm{y}\right]$ & 110.74 & 118.93 & 108.70 & 111.53 \\
\cline { 2 - 6 } SW & $\eta[\%]$ & 11.54 & 11.56 & 11.58 & 11.54 \\
\hline
\end{tabular}

The influence of orientation over the yearly energy production has the same tendency for all cities. Generally, the order from highest to lowest energy production is: vertical-S, vertical-SE, vertical-SW. Taking into account that for SE and SW orientations the amount of solar radiation on vertical surfaces is approximately equal, the lower energy production on SW, Tab 2, could be determined by higher operating temperatures of $\mathrm{PV}$ panels during afternoons.

The analysis is also detailed for monthly intervals in Tab 3. The information is presented as energy produced for the maximum month. Also, in the energy produced ( $E$ $\left.\left[\mathrm{kWh} / \mathrm{m}^{2}\right]\right)$ column, right next to the numerical value, is marked the information referring to the time in the year when it is achieved. For monthly analysis, Tab 3, the results are showing that the maximum production months for vertical-south position in almost all cases are reached during the late summer days or beginning of the autumn. The maximum month for vertical-SE and vertical-SW is almost always August, even the monthly efficiency registered (11.32-11.45\%) is lower than the annual one (11.54-11.66\%).

Table 3. Results for monthly analysis.

\begin{tabular}{|c|c|c|c|c|c|}
\hline \multicolumn{2}{|c|}{ Position / Location } & B & CJ & IS & TM \\
\hline \multirow{3}{*}{ Vertical-S } & $E\left[\mathrm{kWh} / \mathrm{m}^{2} \cdot \mathrm{m}\right]$ & 12.99 & 13.39 & 12.44 & 12.90 \\
\cline { 2 - 6 } & $\eta[\%]$ & 11.44 & 11.47 & 11.41 & 11.47 \\
\cline { 2 - 6 } & Month & Sept & Oct & Aug & Sept \\
\hline \multirow{3}{*}{ Vertical-SE } & $E\left[\mathrm{kWh} / \mathrm{m}^{2} \cdot \mathrm{m}\right]$ & 12.62 & 13.07 & 13.14 & 12.53 \\
\cline { 2 - 6 } & $\eta[\%]$ & 11.36 & 11.45 & 11.43 & 11.41 \\
\cline { 2 - 6 } & Month & Aug & Aug & Aug & Aug \\
\hline \multirow{3}{*}{ Vertical-SW } & $E\left[\mathrm{kWh} / \mathrm{m}^{2} \cdot \mathrm{m}\right]$ & 12.25 & 13.30 & 13.03 & 12.38 \\
\cline { 2 - 6 } & $\eta[\%]$ & 11.35 & 11.36 & 11.32 & 11.33 \\
\cline { 2 - 6 } & Month & July & Aug & Aug & Aug \\
\hline
\end{tabular}

\section{Conclusions}

Taking into account that for large cities the available horizontal surface is limited both on buildings and on the ground level, the vertical integration of PV panels was 
studied. The analysis of the four locations emphasizes that the influence of the orientation of the PV panels integrated on facades over the annual energy production has the same tendency for all cities. The highest energy production is achieved for vertical-S (126.5 $\mathrm{kWh} / \mathrm{m}^{2}$ year), while for vertical-SE and vertical-SW the values are laying in the $107.9-118.9 \mathrm{kWh} / \mathrm{m}^{2}$ year interval.

The yearly average efficiency of PV panel varies from $11.54-11.66 \%$. The monthly efficiency is lower than the yearly one, $11.32-11.45 \%$, while for the maximum production day, the values are even smaller, between $10.83-11.66 \%$. The efficiency has minimum values during the maximum production day because of the higher operating temperatures when there are registered high solar radiation levels. The results of the analysis confirm that the efficiency of PV panels is positively influenced by incident solar radiation and negatively influenced by cell's operating temperature.

In order to improve the efficiency of photovoltaic panels during hot days of summer, there are techniques for air cooling or water-cooling that can be used. For example, the water cooling of photovoltaic panels is advantageous because the cold water from supply system represents an inexpensive source of energy, with optimum parameters for extracting the excess of heat from PV panels. By using a PV/T system, the efficiency of the entire system would be increased, compared to the simple photovoltaic system, while de return on investment is shorter. Though, in case of PV/T systems, the aim must always consist in raising PV panel efficiency and the extraction of heat must be achieved with as low as possible auxiliary power consumption.

\section{References}

1. http://www.pveducation.org.

2. G.M., Masters. Renewable and Efficient Electric Power Systems, ISBN 0-471-28060-7 (2004).

3. N. Asim, K. Sopian, S. Ahmadi, K. Saeedfar, M.A. Alghoul, O. Saadatian, S.H. Zaidi, A review on the role of materials science in solar cells, Renewable and Sustainable Energy Reviews 16; (2012) 58345847.

4. http://energyinformative.org.

5. A.R. Jordeh. Parameter estimation of solar PV cells: A review, Renewable and Sustainable Energy Reviews 61; (2016), p. 354-371.

6. Bloomberg New Energy Finance.

7. www.pv.energytrend.com.

8. https://upload.wikimedia.org/wikipedia.

9. R.M. Swanson. A vision for crystalline silicon photovoltaics, Progress in Photovoltaics: Research and Applications 14; (2006), p. 443-453.

10. http://www.ctsolarservices.com/ct-solar-servicesphotovoltaics.html.

11. Y. Du, C.J. Fell, B. Duck, D. Chen, K. Liffman, Y. Zhang, M. Gu, Y. Zhu. Evaluation of photovoltaic panel temperature in realistic scenarios, Energy Conversion and Management 108; (2016), p. 60-67.
12. S. Dubey, J.N. Sarvaiya, B Seshadri. Temperature Dependent Photovoltaic (PV) Efficiency and Its Effect on PV Production in the World: A Review, Energy Procedia 33; (2013), p. $311-321$.

13. V.J. Fesharaki, M. Dehghani, J.J. Fesharaki. The Effect of Temperature on Photovoltaic Cell Efficiency, Proceedings of the 1st International Conference on ETEC, Tehran, Iran; (2011).

14. http://www.solar-facts.com/panels/panelefficiency.php.

15. S.V. Hudisteanu, M. Pruteanu, T.D. Mateescu, M. Vasilache, Experimental investigation of temperature effects on the parameters of photovoltaic panels, Journal Environmental Engineering \& Management Journal, Volume 16, Issue 7 (2017).

16. E. Skoplaki, J.A. Palyvos. On the temperature dependence of photovoltaic module electrical performance: A review of efficiency/power correlations, Solar Energy 83; (2009), p. 614-624.

17. E. Cuce, T. Bali, S.A. Sekucoglu. Effects of passive cooling on performance of silicon photovoltaic cells, International Journal of Low-Carbon Technologies; (2011), p. 1-10.

18. C.G. Popovici, S.V. Hudișteanu, T.D. Mateescu, N.C. Cherecheș. Efficiency improvement of photovoltaic panels by using air cooled heat sinks, Energy Procedia 85; (2016), p. 425 - 432.

19. J.K. Tonui, Y. Tripanagnostopoulos. Improved PV/T solar collectors with heat extraction by forced or natural air circulation, Renewable Energy 32; (2007), p. 623-637.

20. V.S. Hudisteanu, T.D. Mateescu, N.C. Chereches, C.G. Popovici. Numerical study of air-cooling photovoltaic panels using heat sinks, Romanian Journal of Civil Engineering, Vol. 6, No. 1; (2015), p. 11-20.

21. S.V. Hudișteanu, C.G. Popovici, T.D. Mateescu, N.C. Cherecheș, Efficiency analysis of BIPV systems for different locations in Romania, Energy Procedia, Vol. 112, (2017), pp. $404-411$.

22. B.K. Koyunbaba, Z. Yilmaz, K. Ulgen. An approach for energy modeling of a building integrated photovoltaic (BIPV) Trombe wall systems, Energy and Buildings 67; (2013), p. 680-688.

23. C.-G. Popovici, V.V. Cirlan, T.D. Mateescu, N.-C. Chereches, S.V. Hudisteanu, Influence of various angles of the venetian blind on the efficiency of a double skin façade, Energy Procedia 85, 416-424 (2016).

24. A. Chatzipanagi, F. Frontini, A. Virtuani. BIPVtemp: A demonstrative BIPV installation, Applied Energy 173; (2016), p. 1-12.

25. http://www.onyxsolar.com.

26. http://www.tsolpv.com.

27. J.C. Tovarovic. Integrating photovoltaics into media facades, Annual Conference of Advanced Building Skins, Bressanone, Italy; (2014). 
28. Dye solar cell, Annual Conference of Advanced Building Skins, Bressanone, Italy; (2014).

29. M.C. Jubayer. Numerical modelling of forced convective heat transfer from the inclined windward roof of a low-rise building with application to photovoltaic/thermal systems, Master Thesis, The University of Western Ontario London, Ontario, Canada; (2010).

30. Z. Wang, F. Qiu, W. Yang, X. Zhao, S. Mei. Experimental investigation of the thermal and electrical performance of the heat pipe BIPV/T system with metal wires, Applied Energy 170; (2016), p. 314-323.

31. R.A. Agathokleous, S. Kalogirou. Double skin facades (DSF) and building integrated photovoltaics (BIPV): A review of configurations and heat transfer characteristics, Renewable Energy 89; (2016), p.743756.

32. C.-G Popovici, S.V. Hudişteanu, T.D. Mateescu, N.C. Cherecheş, (2016), Efficiency improvement of PV panels by using air cooled heat sinks, Energy Procedia, 85, 425-432.

33. E. Vuong, R. Kamel, A.S. Fung. Modelling and Simulation of BIPV in EnergyPlus and TRNSYS, Energy Procedia 78; (2015), p. 1883 - 1888.

34. V.S. Hudişteanu, T.D. Mateescu, C.G. Popovici. Five parameter model of photovoltaic panel implemented in MATLAB/Simulink, The Bulletin of the Polytechnic Institute of Jassy, ConstructionArchitecture Section, T. LXI (LXV), Fasc. 3; (2015), p. 93-102.

35. M.P. Aparicio, J Pelegrí-Sebastiá, T Sogorb, V Llario. Modeling of Photovoltaic Cell Using Free Software Application for Training and Design Circuit in Photovoltaic Solar Energy, New Developments in Renewable Energy; (2013), p. 121-139.

36. TRNSYS 16 Database. 